\title{
Complex Global Microstructures
}

The New Terrorist Societies

\author{
Karin Knorr Cetina
}

$\mathrm{T}$

HE NEW terrorism, as the 9/11 Commission Report of the US Congress and President terms it, is sophisticated, patient, disciplined and lethal (Kean and Hamilton, 2004: xvi, 47ff;; see also Hall, 2004). The $9 / 11$ attack was a complex international operation that could not have been mounted by just anyone in any place. Such an operation required, the Commission states at the end of a long and detailed investigation, a logistics network able to manage the movement of operatives and money. It had to find and transport resources, and it had to have reliable communication between coordinators and operatives, a command structure, planning, the ability to test plans, recruitment and training (Kean and Hamilton, 2004: 365-6). Such operations demand a sophisticated global counterterrorism strategy - it will not suffice to simply launch a war (e.g. against Afghanistan) or to mobilize a nation in homeland defense. Countering terrorism will have to become a truly global effort involving a coalition of governments, extending to remote regions of the world, engaging the global struggle of ideas, and translating short-term concerns into long-term internal and external commitments (2004: $363 \mathrm{ff}$.). And yet what makes this formidable mobilization necessary is not an omnipotent evil empire, a massive multinational corporate structure or a military-industrial complex. The Commission speaks of the active support of 'thousands' of young Muslims for bin Laden's message, not of millions (2004: 362). It also states that the group of conspirators that brought off the attacks was at the same time fragile, dependent on a few key personalities, and occasionally left vulnerable by the marginal, unstable people often attracted to such causes (2004: 364).

How, then, are we to conceptualize sociologically this 'hydra of destruction' which is simultaneously no more than a marginal group of conspirators that makes mistakes, whose tradecraft is not especially sophisticated and which lives from donations? The new terrorism would seem to

Konstanzer Online-Publikations-System (KOPS)

URN: http:I/nbn-resolving delurn:nbn:de:bsz:352-opus-80987

URL: http://kops.ub.uni-konstanz.de/volltexte/2009/8098/ 
be a major exemplifying case for complexity theory - for example, it exemplifies major disproportionalities between cause and effect, unpredictable outcomes and.self-organizing, emergent structures. Complexity is geared to just such (seeming) contradictions as the disproportion between a fragile group of plotters and the devastating global effects of their actions. Yet complexity theory concepts only point us back to social science questions: what, for example, are the social morphologies of groups are that are capable of such asymmetry effects? In fact, complexity concepts may be most relevant today as pointers to a changing landscape of such morphologies. Modern, industrial society created 'complex' forms of organizations that managed uncertainty and task fulfillment through interiorized systems of control and expertise. But complexity was institutional complexity; it meant sophisticated multi-level mechanisms of coordination, authority and compensation that assured orderly functioning and performance. A global society leans towards a different form of complexity; one emanating from more microstructural arrangements and the rise of mechanisms of coordination akin to those found in interaction systems.

And it is as a microstructural arrangement that the new terrorism interests me here. The new global terrorism, I want to argue in this article, illustrates the emergence of global microstructures; of forms of connectivity and coordination that combine global reach with microstructural mechanisms that instantiate self-organizing principles and patterns. Global microstructures have been documented before in areas such as financial markets (Knorr Cetina, 2004; Knorn Cetina and Bruegger, 2002; MacKenzie, 2004). I suggest that this concept can be useful in contexts other than global markets, while also pointing out, however, that the terrorist microstructure we confront has different constitutive elements. The basic intuition that motivates the concept of a global microstructure is that genuinely global forms, by which 1 mean fields of practice that link up and stretch across all time zones (or have the potential to do so), need not imply further expansions of social institutional complexity. In fact, they may become feasible only if they avoid complex institutional structures. Global financial markets for example, where microstructures have been found, simply outrun the capacity of such structures. These markets are too fast, and change too quickly to be 'contained' by institutional orders. ${ }^{1}$ Global systems based on microstructural principles do not exhibit institutional complexity but rather the asymmetries, unpredictabilities and playfulness of complex (and dispersed) interaction patterns; ${ }^{2}$ a complexity that results, in John Urry's tenns, from a situation where order is not the outcome of purified social processes and is always intertwined with chaos (2003: 106, 17-38; see also Hpbart and Schiffman, 1998: 235-59; Thrift, 1999). More concretely, these systems, manifest an observational and temporal dynamics that is fundamental to their connectivity, auto-affective principles of self-motivation, forms of outsourcing', and principles of content that substitute for the principles and mechanisms of the modern, complex organization.

If the basic intuition given before is correct, microsociology - and the methodology of qualitative research - provide significant resources for the study of global systems. A further resource is provided by complexity concepts: in Al Qaeda's case, these can be usefully deployed to illuminate and analyze the surprising power and success of its global microstructural configuration. ${ }^{3}$ The analysis of global microstructures then helps to collect and assess empirical evidence for the architecture of the global structural forms of a world society (see also Stichweh, 2000). It also suggests a theory of microglobalization - the view that the texture of a global world becomes articulated through microstructural patterns that develop in the shadow of (but liberated from) national and local institutional patterns. Microglobalization implies that the micro (in the sense of micro-principles of patterning) and the macro (in the sense of global scope and extension) should not be seen as two levels of empirical reality that stand in contrast to one another. Rather, the micro in the form indicated instantiates the macro; micro-principles enable and implement macro-extension and macroeffects. ${ }^{4}$

\section{What Are Global MicrosLrnctures?}

I have conceptualized global microstructures as structures of connectivity and integration that are global in scope but microsociological in character. I now want to emphasize four characteristics of global microstruclures: they are 'light', institutionally speaking, as implied before; they appear to facilitate a certain non-Weberian effectiveness; they cannot simply be reduced to networks; and they exhibit temporal complexity. Let us first consider lightness. By 'lightness' I mean that the mechanisms and structures involved suggest a reversal of the historical trend toward formal, rationalized (bureaucratic organizational) structures whose beginning appears to date back to the medieval church (Lancaster, 2005). Thus while microstructures are on some level organized or coordinated systems, the coordinating elements involved are not of the kind we associate with formal authority, complex hierarchies, rationalized procedure or deep institutional structures. In fact, the mechanisms involved may be akin to the ones we find in face-to-face situations, but at the same time they hold together arrangements at a distance and distributed systems. A second characteristic of global microstructures pertains to the relationship between institutional lightness and the achievement of effects. Weber's notion of rationalization was radical in that it postulated a particular organizing structure composed of legitimate authority, formal expertise and rational, instrumental procedure as an effective agent of modernization. The structure underlies not only the effectiveness of capitalist production economies, but also that of public service sectors and nation state administrations. Postmodern consumer society also owes its success to a significant degree, it is plausibly argued, to the presence and proper functioning of such rationalized systems (e.g. Ritzer, 1994, 2002). While global microstructures do not correspond to Weberian ideals of highly rationalized systems they appear nonetheless effective. And this effectiveness relies to a far greater extent than hitherto on the 
systematic and reflexive use of systems of amplification and augmentation. Such strategies seek and exploit the potential for disproportionalities between input and output or effort and effect, and they can overcome disproportionalities between actors who pursue conflicting goals (see Cohen and Stewart, 1994; Uny, 2003: 7). Disproportionality effects can be distilled, for example, from the use of technology, from scientific and other innovations, and from 'media' of various kinds used as amplifying and multiplying systems. Global microstructures may also derive disproportionality benefits from decoupling internal operations from support structures that provide for the conditions under which operations can remain light; 'outsourcings' of this kind also point away from the inclusive notion of an internally rationalized system. Finally, lightness may emerge in response to de- or underregulation, which create the space for an adaptive and adaptable self-organization.

A third characteristic of global microstructures is that they are not simply networks, though they may comprise a variety of relational arrangements. Networks are sparse social structures (e.g. Fligstein, 1996: 657; White, 1992: 65-6); they essentially consist of channels or 'pipes' (Podolny, 2001) through which information and resources flow between nodes. ${ }^{5}$ What flows through the channels carries much of the burden of explaining outcomes, as does participants' selection of network channels over other means of distribution or coordination. But more is going on in global social forms than transfers between actors. ${ }^{6}$ For example, it would seem to be difficult to understand Al Qaeda without taking into account the spiritual influence of Islamist religious representations, or its family structure and self-reproducing mechanisms. The term 'microstructure' is intended to point to the richness and diversity of elements and practices that layer global social forms. It is also intended to suggest that relational connectivity may not be enough to effectively organize complex systems. Thus while all elements may play a role in organizing or integrating a microstructure, I want to specifically point to scopic media (see below) as mechanisms of coordination on a global scale. Scopic media enable flow architectures that are not territorially bound, but the specific character of these architectures varies greatly across microstructured systems. For example, global institutional currency markets, which can also be seen as global microstructures and which are entirely electronic markets, include a level of intersubjectivity that derives from the character of these markets as reflexively observed by participants in temporal continuity, synchronicity and immediacy. These markets are communities of time, but in a different sense than the terrorist groups for which disconnections and 'structural holes' are a characteristic of operative practice. Though global microstructures tend to be flat rather than hierarchically organized systems, they are at the same time highly textured systems. The specific textures re-specify and may in fact contradict assumptions about network structures (e.g. Knorr Cetina, 2003).

The time aspects just mentioned point to a fourth characteristic of global microstructures that I would like to emphasize here. There is more than one temporal dimension that is of interest, but 1 want to specifically note the relevance of what Luhmann once called the 'temporalization of complexity' (1978) for understanding these systems. The notion can be illustrated if we consider systems (say Al Qaeda) in relation to their environment (that of the societies in which Al Qaeda operates) and in relation to their components. One of the ideas here is that temporally unstable components increase the complexity and thereby the stability of the larger system, since non-enduring components change in response to the irrita-1 tions of an (always more) complex environment and help the larger system cope with external factors. ${ }^{7}$ In other words, it is non-entrenched, 'nervous', degenerating elements that recreate themselves differently over time that carry the system forward Another way to put it is that continual disintegration creates the space for successor-elements and this increases the complexity and the chances of survival of the overall system (Luhmann, 1984: 76-81; Zeleny, 1981:4-17). Note that this notion is in contrast, to network notions that see strong and expanding rates of relatedness between units whose identity is unproblematically assumed as a guarantee of success. ${ }^{8}$ The contrasting assumption here is that the temporalization of elements leads to a continual change of patterns of relatedness, and this is a causal factor in the successful reproduction of the system. These concepts refer back to the notion that autopoielic systems are emergent and do not have (stable) 'foundations' (compare Uny's metaphor of a hologram for an emergent system, 2003: 51). A second idea that illustrates what temporal complexity might mean is that spatially distributed configurations can be made more complex when they become part of a temporal stream. To give an example from the area of financial markets, spatially dispersed knowledge about prices and dispersed interests in trading have become integrated, since the $1980 \mathrm{~s}$, into a temporal stream of activities made possible by electronic information and dealing systems that connected participants across locations and time zones (Knorr Cetina, 2003). This development eliminated arbitrage as a form of transaction that exploits differences of information across space; but it can also be argued that the transformation of a spatial into a temporal system increased the liquidity and innovativeness of market transactions. Thus it is the sequentialization of the market, its transformation into a global (rather than nationally or culturally differentiated) flow structure, which arguably contributed to the enormous growth, power and reproduction of financial markets. ${ }^{9}$ Al Qaeda, it appears, also treats its units and components as temporal elements, and it has succeeded in creating a complex global stream that appears more successful than locally and nationally operating terrorist groups.

In the following, I will pursue some of these concepts in relation to $\mathrm{Al}$ Qaeda. I first discuss transcendent time as a structure of parallel living, and then tum to the scopic systems through which the terrorist project becomes assembled and channeled as a network-transcendent enterprise. This will also allow me to illustrate some of the amplification effects that render the terrorist project effective. The section 'Cells and Disporas' extends the 
argument by focusing on Al Qaeda's dual organization in terms of cells and diasporas. It relates the temporal complexity I associate with its cell structure back to transcendent time. These elements will also help to articulate the disproportionality effects and emergent features with which the new terrorism is associated.

\section{Transcendent Time: A Structure of Parallel Living}

I now want to focus directly on Al Qaeda, starting with the religious and symbolic dimension of the new terrorism, which provides the existential underpinning for, it would seem, all its activities. While the Muslim belief system of AI Qaeda clearly has many aspects, I want to discuss it in terms of the lived time that potentially connects the members of the group. This may help in understanding the character of Al Qaeda terrorism as a parallel world disjoined from the world of the host societies in which Al Qaeda volunteers live. A useful approach in this regard is to go back to early Christian communities and the way they lived time, according to Heidegger (2004; see also Ciborra, 2004: 23ff.; Guignon, 2000). Heidegger reconstructs the temporality of these communities fron St Paul's letter to the Thessalonians. According to St Paul, at the beginning of primal Christian spirituality lies the Annunciation as an experience that shapes religious life at the time and is, for the individual and the community, a moment of transformation. St Paul refers to the 'having become' that characterizes Christians alter the Annunciation. We can also draw on Kirkegaard here, for whom such 'moments', which can be extended, suggest the beginning of an unconditional commitment that comes to define one's world and that redifferenliates the content of one's past and future (Dreyfus, 1993: 321). In early Christian religiosity there is also the prospect of the 'second coming' and the burning question when this event will happen. St Paul addresses the question by indicating how one should live the situation of waiting: it is not a matter of simply awaiting this future occurrence but instead of 'running forward' towards it by living every moment in a distinctive way. In this 'living-forward' one is resolute in assuming a context shaped by having become a Christian in order to be prepared for the Event which is already happening. Life becomes simplified in a certain manner as it is 'brought into the simplicity of its fate' and pulled back from 'the endless multiplicity of possibilities which offer themselves' (Guignon, 2000: 88-9). As the later Heidegger states, the world 'does not become another in its content, nor does the circle of others get exchanged for a new one'. Rather the transformation pertains to the 'form' of everyday activity, leaving the content of the world unchanged (Dreyfus, 1993: $32 \mathrm{ff}$ ). Thus, those who 'have become' will still go about the business of everyday life and attend to what is demanded of them. But they will do so in a different mode; what has changed, in a term borrowed from Williams (1977: ch. 9), is a structure of feeling, and the living of time.

I want to propose that such a 'futural' mode of living based on a 'having become' can also be seen to characterize the new religious terrorism. Like the early Christians confronting an eschatological promise, many members of AI Qaeda would seem to similarly ground their life in 'moments' of transformation. They also appear to be pulled into living-forward toward the end a parallel life that has been delivered over to a new temporality and commitment, while they are at the same time participating in the business of ordinary life. In the terrorist case, the new temporality appears to actively confront, if not embrace, the possibility of personal death - as a transitional occurrence en route to a promised and visually pictured personal paradise. But it also runs forward toward an imagined and ecstatic success of jihad as 'holy war' beyond personal death and toward the future of the community in whose history one's own death is enmeshed. These more collective ideas run counter to the Heideggerian concept of time as individual being-towarddeath. Thus, the lived time of terrorism appears 'transcendent' in regard to personal life, and it transcends ordinary time by 'shadowing' it with a second future that embeds everyday activities within a new meaning structure.

The assumption of a second transcendent temporal structure of terrorism is important in the following respects. First, it grounds modes of affectivity that appear to have served Al Qaeda in the past: two characteristic aspects of these activities have beenpatien.ee and preparedness: the patience to wait for the right situation to strike while at the same time resolutely preparing for specific attacks, and the patience to call off projects and accept setbacks while simultaneously reorganizing and living-forward toward the goal of an Islamic state. The members of Al Qaeda are not improvisers who act on the spur of the moment or in response to fleeting circumstances. But neither are they given to the strict schedules and modes of control that characterize rationalized systems of planning. As analysts have noted, Al Qaeda has shown a surprising degree of patience, sometimes giving itself years ol meticulous preparation without any indication of hurry or deadline pressure (Kean and Hamilton, 2004: ch. 5.2). At the same time, participants have undergone extensive preparatory training, often for concrete tasks (e.g. Gunaratna, 2003: 10-12); in other words, they resolutely assumed the context of becoming a fighter for a cause in order to be prepared for demands when they call. Patience and preparedness also serve, one assumes, Islamic faith as a continually accomplished and emerging form, as something that must be repeated and renewed through prayer and that continually discloses itself further through sermons and discussion. More generally speaking, to live a time outside regular time - while continually tapping into the latter and taking one's cues from it - may help account for the robust capacity of Al Qaeda to regenerate itself, on which many authors have commented (e.g. Gunaratna, 2003: 72).

Second, this sort of temporality would also appear to bind together an otherwise dispersed and diverse community whose members derive endurance, tension and lived significance from the act of giving themselves over to transcendent time. Al Qaeda membership cuts across national, cultural and language boundaries, and it includes and liaises with different Muslim religious orientations. Osama bin Laden has continually stressed 
the need for Muslims of different orientations to unite in the fight against Americans and 'the degradation and disbelicf which have spread in Muslim lands'- ${ }^{10}$ Temporal coordination alleviates the problem of constructing unity from diversity and the problem of 'other minds', that is, of closely coordinating and shaping individuals' thinking. It suggests that a level of intersubjectivity may develop among participants who live different daily lives and have experienced various cultural upbringings and national situations For this argument to be plausible one needs to consider that transcendent time involves more than time reconstructed in terms of a new beginning and end; it also implies time-structuring - a temporality punctuated by events which include widely conmunicated historical experiences and references (such as the Afghan war against Russia or the abolition of the Caliphate in 1924, see later), successful terrorist attacks, public summons (fatwas), sermons and television appearances (e.g. bin Laden's appearance before the US election of November 2004). Thus transcendent time would appear to be structured in terms of a historical sequence to which participants are oriented and which contextualizes individual lime and effort. The sequence provides not only for a collective memory of the group, it also situates the collective project that is continually reinstantiated, extended and reshaped as events are incorporated into the historical sequence. Time, here, may have to be thought of as a 'punctuated flow' (punctuated by a sequence of occurrences) into which individual participants are absorbed and feel integrated, a flow that runs on in the shadow of everyday time and the temporal orders of host cultures.

One implication of the temporal coordination postulated is that globality becomes possible as spatial mechanisms of coordination based on geographic closeness, routine face-to-face contacts, national political knowledge and the like lose their importance. Another implication is that - as a form of coordination - the temporality postulated fulfills some of the functions Weber associated with rational authority structures. In other words, the theoretical argument here is that time-structuring affords a form of coordination that can take the place of institutional control and social authority structures. We have thus taken a first step towards articulating the new terrorism as a microstructure that operates on a global scale. In the languagc of complex systems, temporal coordination of the kind postulated foreshadows temporal complexity, a notion I will return to at a later stage.

\section{Scopic Media and the Information Societies of the New}

\section{Terrorism}

In this section, I want to introduce scopic media as a mechanism that points away Irom relational connectivity, thus indicating that global microstructures are more than simply networks. My starting point is that the punctuated flow I postulated can only emerge and have integrative effects if the relevant events are widely transmitted. Here we need to consider a further element of the new terrorism, the role of teletechnologies as the components of a dispersed 'scopic' system through which the collective terrorist project becomes assembled and channeled. I emphasize here the role of technologies in enabling and shaping the new terrorism. Its technological conditions of production lie not with the equipment of attack, which is often pre-modern (recall the knives the 9/11 terrorists used on the planes), but with the use of equipment of communication and mediation that enable global coordination. The term '-scope', derived from the Greek 'scopein', to see, when combined with a qualifying notion, means an instrument for seeing or observing, as in 'periscope'. Social scientists tend to think in terms of mechanisms of coordination, which is what the network notion stands for, a network is an arrangement of nodes tied together by relationships which serve as conduits of communication, resources and other coordinating instances that hold the arrangement together by passing between the nodes. But we should also think in terms of reflexive mechanisms of observation and projection, which the relational vocabulary does not capture. Like an array of crystals acting as lenses that collect light, focusing it on one point, such mechanisms collect and focus activities, interests and events, and project them in identical fashion to dispersed audiences. An ordinary observer who monitors events is an instrument for seeing. When such an ordinary observer constructs a textual or visual rendering of the observed and televises it to an audience, the audience may start to react to the features of the reflected, presented reality rather than to the embodied, pre-reflexive occurrences. The scopic system acts as a centering and mediating device through which things become assembled and from which they are projected forward. In Al Qaeda's case, the reflexive mechanisms of encapsulation and projection are teletechnologies (see Glough, 2000: 3), such as television channels, the web, videotapes and audiotapes, and their producers. These media provide sensorily rich records and projection planes for the transmission of images, speeches, commentary and events. The technical systems are 'apresentational' (the term is derived from Schutz and Luckmann, 1973, who spell it appresentation) in the sense of 'bringing near' to receivers distant situations that are out of reach for ordinary lifeworlds. They are also a-representational, by which I mean that the content of the televised items should not be primarily decoded in a representational idiom. Though the representational truth of these items may well be invoked, the contents tend to be media productions by television stations and by authors such as religious leaders aiming at a range of performative effects. Raised to a level of analytic abstraction, the teletechnological media and media contents correspond to a scopic system that fills transcendent time with collective content, structures time in terms of events, and gives concreteness and substance to the temporal coordination I have postulated. Many of the broadcast events are also intentionally moral and peiformative in the sense of 'calling' the audience to particular forms of actions. These calls, exemplified by bin Laden's declaration of war against the Americans of February 1998, or his and Ayman al-Zawahiri's 'messages' of warning and threat in 2002, are not of the same order as the exchanges that coordinate concrete plans of action. But they may well have coordinating force on another level: 
that of reiterating and extending the transcendent project, to which the audience is committed, that of renuwing an affective community, and that of creating for this community a background world that grounds their activities and experiences.

Thus, if the scopic mechanism I have postulated transcends network connectivity by being a mirroring device, it also transcends it by being a contextualizing mechanism. A scopic system presents identical images and messages to a diverse audience - the content either travels to this audience in the form of audio- and video-cassettes, or it travels to it through broadcasting channels. One assumes that the images and messages have a binding effect on prepared participants, as these select and interpret the content within the framework of already existing commitments to a transcendent project. One also assumes that for those 'having become' and regularly drawing on scopic presentations, the sequences of occurrences begin to constitute something of a referential world - a thick context that situates individual activities, provides frameworks of interpretation for further events, and is a venue for the renewal of emotional dedication. When scopic systems are systematically used they have 'world-making' (Goodman, 1978) effects.

The world involved is informational rather than 'natural' or 'material'. This is implied by the notion of scopic systems and the mediated character of the communities they create. In communicating distant occurrences in identical fashion to distributed, diasporic audiences, scopic systems are information systems - and Al Qaeda is part of the contemporary information society in that it uses its means and mechanisms. The informational makeup of this world is also apparent in its processual character. Most of our world notions imply that the world is a place (however extended) or perhaps a totality of objects (e.g. the physical universe) 'wherein' we live, and 'in' which factual (e.g. globalization) and symbolic processes can be said to take place. The defining characteristic of this sort of world is that it is given or presupposed. In its presupposed nature, it cannot, be made intelligible by the things that happen 'in' the world; the world has a distinctive structure of its own that differs from the things that happen in it. This background structure is seen to be material, social (it is interpreted) and territorial. In comparison, the parallel world of Al Qaeda appears to be fluid, processual and aterritorial. It is neither presupposed nor given, but constructed-ingoing-along. As the flow of events into which Al Qaeda members are plugged is continuously reiterated, updated and extended, the various temporal and other coordinates of this world are continuously articulated and changed as operational goals are adopted, religious commentary and messages are interpreted, new decrees are issued, and the activities of various 'enemies' are observed and decoded. The very accoutrements of this non-institutional timeworld change as new events take place and become food for imagined new scenarios and works. If the image 1 used in the section 'Transcendent Time', of Al Qaeda 'running-forward' towards the future by living every moment in a distinctive way is plausible, then it implies that Al Qaeda's world is dynamic and quickly changing rather than static and in a state of equilibrium. This dynamism has a correlate in the mobility of participants. We know from various records and descriptions that Al Qaeda members themselves, and their camps, cells and other bases, are extremely mobile, Participants travel, move and change identity frequently. Cells are equally mobile, and the membership, leadership and operational structure of the group also change. Some of the mobility of participants is motivated by the need to maintain secrecy and to avoid, or respond to, capture; but mobility also resides in the recruitment process which brings potential recruits from global locations to training sites and then channels them to new locations; and it is part of the planning of attacks that are executed in global locations. The mobility of Al Qaeda surely is a strategic element in its success; but it also points to the 'placeless' character of the Al Qaeda microstructure, its floating, scape-like (Appadurai, 1996: ch. 2) form and the readiness of participants to interlock with any territory for specific purposes but to become part of none.

Al Qaeda's mobility supports the notion that it is time dimensions rather than spatial coordinates that span and link up this lifeworld. But it also points to another aspect of the dynamism of this world, which is the incentive-offering and affective character of information transmitted by scopic systems. Al Qaeda members inhabit a visually and discursively constructed domain of fragmented and partial information contents pertaining to the religious, the political and to movement. "But they also inhabit a more viscerally constructed word. Al Qaeda members are not passive worshippers of particular fundamentalist religious ideas; as a group, $\mathrm{Al}$ Qaeda is engaged in terrorist activities. Its members are driven, by mediated experiences and their continual interpretations and iterations, to live a particular purpose associated with transcendent time. Much of the communication the Al Qaeda leadership and other relevant persons provide is broadly spiritual in accordance with the religious and symbolic underpinning of the group. But it is also at the same time incentivizing political and practical communication that defines goals and enemies, calls sympathizers to action, instrupts them in concrete behavior, specifies grievances, and threatens and warns the counterparties in the engagement. According to a quantitative analysis by Seidensticker (2004: $29 \mathrm{ft}^{\prime \prime}$ ), nearly 90 percent of the 1570 words of the four pages of instructions for the $9 / 11$ attack found in a travel bag of Muhammed Atta's that had not been transferred to his flight to Los Angeles were religious in character. But they were at the same time instructions in how to conquer fear, remain patient, go to the airport, pass through safety doors, sit in one's passenger-seat, slit a victim's throat (kill some victims with knives), take bounty and prepare for the afterlife in paradise. Bin Laden's fatwas (Islamic decrees) of 1996, 1997 and 1998, as well as his more than a handful of videos and interviews of 2001 and his recent declarations on the occasion of the 2004 election in the United States, are all incentivizing communications in whose service religious contents are invoked. More generally speaking, the information transmitted between 
Al Qaeda participants is not only cognitive or symbolic in nature, but has strong sensory and motivating components. This leads us back to scopic mechanisms, which transmit content in potentially rousing fashion to distributed diasporic audiences. The media chosen - television broadcasts and video- and audio-cassettes - have different affordances than the satellite and regular mobile phone and email channels also used by Al Qaeda members. The latter provide for direct bilateral communications and responses; in other words, they are relational media used as interactive channels, the channels of a network form of coordination. Scopic systems, on the other hand, not only provide for a more reflexive form of coordination - their content reflects and maps local occurrences onto a global field - but produce visual and sensory projections. Benedict Anderson famously pointed to the role of newspapers and novels as the means through which readers continually reassure themselves of the existence of millions of others that constitute the imagined community oi the nation - the effect occurs even though readers do not have 'the slightest notion' of the identity of these others (1983: 39ff.). When teletecbnologies rather than written media transmit information, and the context is terrorism, the images transmitted may be of blood and destruction, of revenge and moral outrage, and of martyrs and 'heroic life'. These spectacles of gory bodies and physical expression appeal strongly to emotions. Barthes, in discussing photographs (1980: 88-9), argues thai it is not the shock value and traumatic content of such images, but details that occasionally break out of their flatness and arrest the viewer, throwing him or her into a state of ambivalence and oscillation between certainties. Such details (which Barthes calls the 'punctum' in contrast to the field of flatness of the image) may cause anxieties, provoke intense discussions and may therefore have high radicalizing potential (Srivatsan, 2000: 46-7). What this suggests is that the sensory and visual mode of presentation may help to create not so much imagined communities, bound together by symbols of belonging, as affective communities that are willing to engage in specific actions that recreate the disturbed emotional order. At the very least, we can perhaps assume that the scopic presentations can be seen as a re-incentivizing device for the teleoaflective system of the terrorist project.

Two things should be emphasized in concluding this section. The first is that the grammar of attraction of these scopic presentations appears to draw on established practices of disseminating and circulating religious performances and devotional content in the Muslim world (sermons and teachings, devotional poems, commemorative songs, etc.). Anthropologists and others have documented the use of electronic forms of disseminating religious discourse that shapes Islamic public spheres (e.g. Eikelman and Anderson, 1999). ${ }^{12}$ The recordings appear to serve as performative techniques dedicated to creating pious dispositions in participating subjects. 'They may 'rouse in the soul an overwhelming desire to invoke blessings and salutations' upon the prophet (Kabbani, 2002: 69; see also Hirschkind, 2001). Muslims may interact with these recordings by listening to them repeatedly during regular events or routine activities (e.g. while driving a car), and they use them to prepare for special celebratory and commemorative occasions (Eisenlohr, 2005). The second point is that the practices of electronic recording and transmission appear to play a particular role in diasporic communities; they are said to help overcome a sense of remoteness from the homeland or from centers of Islamic authority among members of these communities. As indicated in the next section, diasporas play a particular role in the new terrorism, and Al Qaeda members themselves lead a diasporic life. It is plain that these techniques of religious transmission and of iterative listening and viewing can be invested with new qualities when they are employed by terrorist groups and their sympathizers. To give an example, Speyer (2002: 33-4) reports such a use in her work on religious conflicts in Indonesia: the production of CDs (here specifically video CDs [VCDs]) of scenes of violence by Christian and Muslim partisans, but circulated only by the latter - in line, one assumes, with existing traditions of religious transmission. The VCDs, which are shared and copied widely, are watched over and over again and, according to Speyer, have few pretensions to accompanying narration apart from 'the insistent, repetitive narrative of victimization resurrected on and out of body parts'. Speyer also comments on the 'the surplus of misinformation and suspicion circulating like wildfire' among the groups; enmity, in this case, becomes codified through collective gossip and imagery as a form of imprecision and obfuscated information. Underlying such uses is the mass appeal of the VCD genre - from favorite songs to favorite scenes of violence - in the Muslim part of this region of the world; they are mass produced, sold in markets and on streets, transnationally popular and said to be 'quite homogenous' when they represent conflicts across regions: 'Ambon's VCDs look much like Kashmir's, Bosnia's, and video representations of Palestine shown in Malaysia and elsewhere' (2002: 33-4).

\section{Cells and Diasporas}

So far I have introduced two major elements of the global microstructure of Al Qaeda - transcendent time as a structure of orientation constitutive of parallel living, and scopic systems that deliver the 'mediated presence' of remote participants and update interpretations and events. The two elements enable a floating global microstructure to emerge and fuel its dynamics. I now want to address a third element, the organizational form of Al Qaeda. Central to the discussion will be the distinction between its cells and a religiously defined Arab diaspora on which Al Qaeda relies for external support. Several theoretical arguments can be linked to this organization. One is that the organizing principles invoked are microstructural; they involve trust, the analogy of family relationships and a cellular organization. The second line of arguments refers once again to complexity concepts. The dual organization accounts for some of Al Qaeda's disproportional effects; it offers an argument for how lightness of structure can be combined with enhanced effectiveness with the help of methods of amplification and 
augmentation. We shall also see, in this section, that lightness of structure amounts to more than a lack of formal, rationalized institutional structures. It implies a transition to a temporal complexity of a kind where system stability depends on and arises from the fluidity and instability of component units.

Consider first the roles of amplification and augmentation in relation to Al Qaeda's organization. In the last section, I cited scopic media as a constitutive feature of the global microstructure of terrorism. Yet some of the most important of these media are not managed or 'owned' by Al Qaeda but are independent agents (e.g. television channels) that broadcast to a wide and predominantly non-terrorist audience. The television channel $A l$ Jazeera records and broadcasts terrorist messages and images, and it produces, in the eyes of some observers, inflammatory programs whose coverage has disturbed not only Washington but also Arab governments. Yet it clearly also caters to the broad concerns of non-terrorist clientele (it reaches an audience of 30 million to 50 million), it prides itself on being independent and impartial, and it is subsidized by and operates out of Qatar, the American-friendly stale and US ally in the Persian Gulf. Terrorist microstructures incorporate and use some teletechnological media, but they also draw on outside systems that are independent of their communities The issue this raises is the 'dual' organization of Al Qaeda: some functions are interiorized within its framework of organization, while others are 'outsourced' to external agents and units not controlled by the Al Qaeda leadership and not directly engaged in its projects. These external components may not live transcendent time, that is, partake in Al Qaeda's parallel mode of living. They are nonetheless implicated in its projects, which they enable and support. In fact, Al Qaeda's 'lightness' of structure can at least partially be explained by the externalization of some crucial components. Al Qaeda practices a form of 'opportunism': it delegates tasks to outside agents, and it takes advantage of outside agents' willing or unintentional promotion of its cause. For example, it takes advantage of mediachannels that broker communications and meanings to a wide audience of spectators, it outsources much of the recruitment process to sales-agents, the radical religious leaders who propagate relevant interpretations of Islam and head religious schools, and it has externalized much of its financing to independent NGOs, Islamic charity organizations, specific churches and the like (for detailed overviews, see Gunaratna, 2003: ch. 3; Kean and Hamilton, 2004: xviii). ${ }^{13}$

Al Qaeda is thus an exclusive rather than an inclusive organization, much like the global microstructures of financial markets described elsewhere (Knorr Cetina and Bruegger, 2002). But it depends on, and draws on, what I will call here, following Ho (2004), a 'diaspora' of Islamic agencies and people. Ho describes the long existence of a diaspora of Arabs from Hadramawt, Yemen, across the Indian Ocean, and its confrontations with the British Empire from the 16th century onward. A diaspora, in this parlance, is not understood as a homogeneous group that spreads out across territories but is a composite; for example, the Hadrami, in their movement throughout the Indian Ocean settled anywhere, intermarried with the local population, and their offspring assimilated or developed a mixed, Creole identity. But there was also a process of homogenization, though not one based on political ideas. The Hadrami movement did not lead to a newempire - as did the movement of the British to the United Stales. Rather, the Hadrami diaspora took the form of a religious mission. Its greatest success may have been the establishment of the Ottoman universal caliphate - but this was abolished by a Turkish parliament in 1924, following colonial confrontations (Ho, 2004: 214-16). Bin Laden is thought to have referred back to the abolition of this Muslim caliphate in his video response to the bombing of Afghanistan on 9 October 2001 , where he recalled events some 80 years before that had humiliated Muslims. He said:

What America tasted today is something of what we have tasted for decades. For eighty-some years, our community has tasted this humiliation and tasted this degradation ... no one heard and no one answered. ... But when the sword came after eighty years to America, hypocrisy appeared and raised its head.

Ho extends his model to the current situation, arguing that bin Laden is a member of the Hadrami diaspora, the geography of his operations from East Africa to the Philippines is an old theater of Arab diasporic mobility and operations, and these geographical parallels mean that, for viewers in South and Southeast Asia, the events unfolding on the television screen have deep historical resonances (2004: 234ff.).

The notion of diaspora, then, recaptures the idea of a religious commitment introduced in the beginning, but it gives it breadth and historical depth: it draws attention to a long-standing and persistent confrontation between a religiously defined Arabic diaspora and various Western empires (first the Portuguese, then the British, the Dutch, and now the US). It also draws attention to historical calls for jihad with the express purpose of mobilizing Muslims against these powers, starting with a book from 1570 entitled Gift of the Jihad Warriors in Matters Regarding the Portuguese that gave the then anti-imperial struggle a legal basis. ${ }^{14}$ To be sure, the diaspora can no longer be regarded as limited to the Indian Ocean. America is not a colonial power, though it may come close to one in the diasporic imagination. Potential historical continuities of the sort implied are accomplished rather than simply given; bin Laden's video response exemplified the invocation and recreation of a historical experience for specific purposes. The Islamic, or even the Hadrami, diaspora is not a 'community' or 'system' but a changing multitude, with only loosely overlapping religious beliefs. The point I want to make by bringing up these historical references is not that the present confrontation echoes past ones precisely, or that it is in fact identical with them. It is rather that Al Qaeda's global reach and microstructural effectiveness is easier to understand if we not only assume the existence of 'sympathizers', but a historically anchored movement of Islamic 
people - with overlapping religious beliefs and a tradition of confrontation with non-Islamic powers - of whom a portion remains connected to the Arab and Islamic world. Awareness of the historical continuities and specific characteristics of such a diaspora may account for Al Qaeda's success in its global support and recruitment efforts. The dual organization I postulated captures the role of this diaspora in providing Al Qaeda with an external belt of potential capital - financial, social, cultural and political capital. According to estimates by the CIA, Al Qaeda can draw on the support of some 6 million to 7 million Muslims worldwide, of which 120,000 are believed to be potential recruits for its violent projects (cited in Gunaratna, 2003: 95). In complexity terms, Al Qaeda's 'few thousand' active members are augmented by millions of supporters that are linked to it by a diasporic history and imagination. In this sense, Al Qaeda can maintain its lightness of structure, while at the same time mustering disproportiona] effectiveness with regard to selected outcomes.

If the existence of a historical diaspora provides a belt of potential resources, what is inside the belt? In other words, how are we to think of the other leg on which Al Qaeda stands, the second component of its dual organization? The consensual answer (for which I draw here on the summary account by Gunaratna, 2003: ch. 3) is that Al Qaeda is organized in terms of a cellular structure. Cells are units of two to 15 members placed in various settings to prepare for certain tasks, or they emerge in a certain place as recruits living in a particular area become committed to Al Qaeda. For example, of the four cells that prepared the 9/11 attacks, one emerged in Muhammad Atta's location of study, Hamburg, where he had originally gone to study architecture and urban planning, and completed a thesis in 1999 at the Hamburg Technical University. He was recruited to become an Al Qaeda member around 1995, underwent training in Afghanistan in 1996-7, and then recruited two more Arabs studying in Germany. The other cells were established independently of each other in the United Arabic Emirates and Malaysia as launch-pads from which to enter the United States. Several other defining characteristics of this cellular structure can be indicated. The first is that cells are independent and self-contained. Gunaratna (2003: 97) recounts that Al Qaeda's structure remains close to that of Egyptian terrorist groups, whose cells were called anguds, which is Arabic for a bunch of grapes. If a grape is plucked from a grapevine, its disappearance does not affect the others. Thus cells appear to have independent bank accounts, and their members may only know of their own role in a project and not of that of other cells. A second characteristic, continuous with the first, is that cells are productive units. For example, cells or their members may come up with their own proposals for terrorist attacks, find ways of assembling the necessary materials and knowledge, carry out relevant research, and even take charge of financing part of the preparatory work and of their own expenses. Third, cells are mobile in regard to location andflexible in regard to membership. New members may join teams, previous members may transfer to other locations, teams may disband and cells may relocate. Though the cell nodes are regional, regional nodes do not have a fixed abode. For example, after Al Qaeda relocated from Sudan to Afghanistan in 1996, its European and North American bureau moved to Turkey and Yemen, and the Turkish bureau moved again to Spain after the arrest of a key figure in Europe in 1998 . $^{15}$ Fourth, the system of communication that links cells to leaders appears fractal and mulalional - an apparent advantage when it comes to preventing transparency and leaks. There were some cell members among those involved in the $9 / 11$ attacks who communicated directly with leaders in Afghanistan, but most cells appear to have been coordinated through 'agent-handlers' who lived near the target location or in the 'hostile zone' of Europe and America - and they reported only to them. This also implies that cell structure is decentralized and without formal hierarchy or system of governance. What substitutes for a formal hierarchy is a family structure in which 'older brothers' may play a greater role than the others. 'Family' frequently stands for nationality. Fifteen of the hijackers of the $9 / 11$ attacks were from Al Qaeda's 'Saudi family', which, perhaps in continuity with Ho's account of the Hadrami diaspora, appears to play a dominant role in Al Qaeda. Families function regionally, but individuals from different national 'families' may also be 'handpicked' and cross-posted outside their regions (2004:98).

A) Qaeda's family organization responds to problems posed by cultural and linguistic barriers in a global organization; Anderson's imagined communities are put to specific uses here (1983). It is worth mentioning that high-energy physicists, in conducting their large-scale experiments staffed by participants from many regions of the world, also frequently team people up according to national origin. But the metaphor of 'family', like the metaphor of brotherhood ingrained in Islam, also appeals to trust and sentiment and suggests the constitution of community, at least potentially. In other words, cells and families, and the modes of diasporic assistance and affiliation they assume, invoke microstructural principles of connectivity and integration. However, I also want to emphasize temporal complexity here. The characteristics of the cell structure I have outlined, in particular the mobility, flexibility and mutability of cells with regard to membership and location, as well as their relative autonomy and planned disintegration, all point to the temporal nature of cells. Cells are not durable units but changing implementations of short-term projects sequentially replaced by new projects - they are units that their creators plan from the outset to abolish, abandon and recreate as non-identical units at a different location Paradoxically, perhaps, it is this instability and nervous irritability of the components of a system associated, in the first section, 'What Are Global Microslructures?', with a complexity based on lime that serves the stability and successful continuation of the whole group. For Luhmann (1978, 1984: ch. 4), 'temporalized' complexity, as he calls it, was simply a way to theorize process in systems theory. According to his reasoning, all social systems display temporalized complexity in the sense that their most elementary components, actions, are temporally limited events rather than stable, 
enduring structures. But this is a formal definition that does not allow us to capture and assess the disproportionality effects that some systems muster while others do not. In other words, it is useful to re-enter the question and ask which systems turn toward temporal complexity on what level, and which do not. The bureaucratically, organized intelligence agencies and military machines that have been mobilized to fight Al Qaeda rely on elaborate interiorized systems of rules, authority and control that offer some legitimacy and transparency of procedure. What they do not offer is $\mathrm{Al}$ Qaeda's lightness of being - manifest here in its sequentially recreated mode of functioning and non-identical cellular structure.

Conclusion: Temporal Complexity and Transcendent Time

Time-based complexity, one should emphasize, is continuous with the fluidity concepts writers on complexity and others have discussed (e.g. Abbott, 2001; Bauman, 2000; de Laet and Mol, 2000; Urry, 2000). Yet the distinction added here between the flexibility and fluidity of the component level of a system and its overall stability is an important one to make; it provides a particular angle on emergence, implies sequential learning on a microstruclural level and refers us back to transcendent time - as a binding mechanism on a global level. A second distinction emphasized previously in this article, and illustrated with respect to financial markets, needs to be brought back into the picture here: that between a spatial arrangement where stability resides in fixed categories and traditions distantiated from one another, and temporal processing that integrates things into a global stream. The natural history approach, according to Foucault and others, was a spatial arrangement of knowledge. Molecular biology (or an experimental system within it) appears today to be a strongly globally integrated stream of processings superimposed on any remaining spatial logic (see Jokisch, 1996: 184-94). Al Qaeda distinguishes itself from all other terrorist groups that are nationally based by the appearance it gives of having become such a global stream. Transcendent time, as described in the first section 'What Are Global Microslruclures?', lies at the heart of this stream. Sustained and extended by the scopic transmission of media content, it provides for a level of bindingness and integration of the terrorist project beyond the coordination of operational performance and mission planning. Beyond the level, that is, of the ever-decaying, ever-regenerated cellular structure. Both levels involve temporal coordinates, but they are of a different reach and involve different decay parameters.

Global microstructures are the densities that emerge from the conjunction of these temporal coordinates and other elements. The notion provided a second resource for the analysis of Al Qaeda. It suggests the relevance of principles oi integration and task coordination that point beyond the interiorized systems of rationality and control of the modern organization, and that also challenge 'networkness' as the sole alternative to such structures. Microstructures appear light, dense and, on more than one level, temporal. One suggestion here is that global forms may in fact be feasible only in relation to such structures. More would have to be said of course to illuminate the terrorist microstructure of $\mathrm{Al}$ Qaeda and its heavyweight counterpart, the anti-terrorist machine. Genuine empirical research by social scientists is still sorely missing in this area. When addressing these systems, one needs to piece together materials from secondary evidence and public sources. It is nonetheless plausible that the new terrorism in particular can serve as a major exemplifying case for complexity concepts as instantiated in global microstructures. We have nowhere else to turn, one might say, when it comes to learning to understand the elusive nature of the new terrorism and its lethal outcomes.

Notes

1. The new terrorism involves different mechanisms, but it also has so far consistently outrun the capacity of state intelligence agencies and their 'vast. lumbering bureaucracies' (Silberman and Robb, 2005) to counter its threat or even track and identify its challenges.

2. I use a phenomenological notion of interaction here. I take my lead from discussions of intersubjectivity (see Knorr Cetina and Bruegget, 2002), but I draw also on the observation of global communities of practice in high-energy physics that turn to content as a principle of coordination (Knorr Cetina, 1999: chs 7 and 8).

3. Though I can only investigate the new global terrorism in this article indirectly, on the basis of data and reports derived from the work of police and security organizations, it is worth noting that these materials result from investigations akin to ethnographic research.

4. I do not use the notion 'micro' here to point to the local or to localizing patterns. Rather, I use it to point to principles of connectivity and association akin to, and perhaps fundamental to, interaction orders.

5. The network interconnections can be inspected for their structural patterns and influence on outcomes. Networks matter since what flows through the channels affects outcomes; for example, connections provide information benefits for those in contact. The restriction of flows to networks also matters - networks may provide added advantages to those included in, and added disadvantages to those excluded from, network distributions of resources.

6. Consider how much of Al Qaeda one can explain by simply doing a network analysis of known participants, as has been attempted (c.g. Sageman, 2004).

7. One illustration here is the transition, in physics, from the idea of elementary particles as siinple spot-like, non-reducible elements to the transitory, decaying subatomic processes of today. In today's physics, it is the non-identity, fluidity and speed of transformation of the basic units of matter that is of interest (see also Jokisch, 1996: 195-8).

8. See Kelly (1998: 23, cited in Ury, 2003: 52). Actor-network theory provides an example of an approach that postulates such an effect.

9. Similarly, Foucaull and Lepenies argue that pre-modern, spatial arrangements and categories of knowledge were replaced by temporal, historical notions as knowledge became 'historical' at the turn of the 19th century, a move that transformed the speed of knowledge production and the growth of knowledge (cited in Jokisch, 1996: 184-94). 
10. Al Qaeda recruitment video cited in Gunaratna (2003: 72).

11. Also relevant here is that the key to the notion of information is not truth in the sense of a correspondence with an independent reality as testified by science, but news, or difference. Things disclose themselves as information in so far as they differ from and are new compared to earlier material. In other words, the notion information points to the fact that Al Qaeda is not engaged in validating beliefs but rather in performing terrorist activities for which information about the changing nature of circumstances and events is a crucial input.

1!. With thanks to Patrick Eisenlohr, who summarizes some of this in his 2005 article.

12. In economic terms, we might say that Al Qaeda works with and relies on externalities, or that it acts as a principal that recruits and relies on external agents to act for itself vis-a-vis a third party.

13. See bin Laden: No Security for America before Security for Palestine' 9 Oct. 2001, cited in Ho, 2004: 234, n40).

14. The story is cited in detail in Ho (2004: 222).

15. Some of these movements and the travels of AI Qaeda members are recounted in great detail in Gunaratna (2003: ch. 3).

\section{References}

Abbott, A. (2001) Chaos of Disciplines. Chicago, IL and London: University of Chicago Press.

Anderson, B. (1983) Imagined Communities: Reflections on the Origin and Spread of Nationalism. London: Verso.

Appadurai, A. (1996) 'Disjunclure and Difference in the Global Cultural Economy' pp. 27-47 in A. Appadurai (ed) Modernity at Large: Cultural Dimensions of Globalization. Minneapolis, MN: University ol Minnesota Press.

Barthes, II. (1980) La, Chambre claire. Paris: Editions de Seuil.

Bauman, Z. (2000) Liquid Modernity. Cambridge: Polity.

Ciborra, C. (2004) Labyrinths of Information. Oxford: Oxford University Press.

Clough, P. (2000) Autoaffection: Unconscious Thought in the Age of Technology.

Minneapolis, MN: University of Minnesota Press.

Cohen, J. and I. Stewart (1994) The Collapse of Chaos. Harmondsworth: Penguin.

De Laet, M. and A. Mol (2000) 'The Zimbabwe Bush Pump: Mechanics of a Fluid

Technology', Social Studies of Science 30(2): 225-63.

Dreyfus, II. (1993) Being-in-the-world: A Commentary on Heidegger's Being and Time, Division I. Cambridge, MA: MTT Press.

Eikelman, D.F. and J.W. Anderson (eds) (1999) New Media in the Muslim World: The Emerging Public Sphere. Bloomington, IN: Indiana University Press.

Eisenlohr, P. (2005) Devotional Genres, Electronic Mediation and Islamic Authority in Mauritius', paper presented at the Political Communication and Society Workshop, University of Chicago, 12 January.

Fligstein, N. (1996) 'Markets as Politics. A Political-cultural Approach to Market Institutions', American Sociological Review 61 : 656-73.

.Goodman, N. (1978) Ways of Woddmaking. Indianapolis, IN: Hackett.

Guignon, C. (2000) 'Philosophy and Authenticity: Heidegger's Search for a Ground for Philosophy', pp. 79-102 in M. Wrathall and J. Malpas (eds) Heidegger, Authenticity and Modernity: Essays in Honor of Hubert L. Dreyfus, Vol. 1. Cambridge, MA MTT Press.

Gunaratna, R. (2003) Inside Al Qaeda: Global Network of Terror. Berkeley, CA: Berkeley Publishing Group

Hall, J.R. (2004) 'Apocalypse 9/11', pp. 25-82 in P. Lucas and T. Robbins (eds) New Religious Movements in the Twenty-first Century. Legal Social and Political Challenges in Global Perspective. London: Routledge.

Heidegger, M. (2004/1920-21) The Phenomenology of Religious Life. Bloomington, IN: Indiana University Press.

Hirschkind, C. (2001) The Ethics of Listening: Cassette-serinon Audition in Contemporary Egypt', American Ethnologist 28(3): 623-49.

Ho, E. (2004) 'Empire through Diasporic Eyes: A View from the Other Boat', Society for Comparative Study of Society and History 10(4175): 210-46.

Hobart, M. and Z. Schiffman (1998) Informution Ages: Literacy, Numeracy and the Computer Revolution. Baltimore, MD and London: Johns Hopkins University Press. Jokisch, R. (1996) 'Logik der Distinktionen. Zur Protologik einer Theorie der Gesellschufl. Opladen: Westdeutscher Verlag.

Kabbani, R. (2002) 'Dislocation and Neglect in Muslim Britain's Ghettos', The Guardian 17 June

Kean, T.H. and L.H. Hamilton (2004) The 9/1/ Report: The National Commission on Terrorist Altacks upon the United Stutes, with Reporting and Analysis by the New York Times. New York: St Martin's Press.

Knom Cetina, K. (1999) Epistemic Cultures: How the Sciences Make Knowledge. Cambridge, MA: Harvard University Press.

Knorr Cetina, K. (2003) 'From Pipes to Scopes', Special Issue on Economic Sociology, Distinction 7: 7-23.

Knorr Cetina, K. (2004) 'Traders' Engagement with Markets: A Postsocial Relationship', pp. 121.42 in A. Amin and N. Thrift (eds) The Blackwell Cultural Economy Reader. Oxford: Blackwell.

Knon Cetina, K. and U. Bruegger. (2002) 'Global Microstnctures: The Virtual Societies of Financial Markets', American Journal of Sociology 107(4): $905-95$. Lancaster, R. (2005) 'The Office of St Peter: The Bureaucratization of the Catholic Church, 1050-1250', Doctoral dissertation, Northwestem University, Evanston, IL. Luhmann, N. (1978) 'Temporalization of Complexity', pp. 95-111 in R.F. Geyer and J. van der Zouwen (eds) Sociocybernetics: An Actor-oriented Social Systems Approach, vol. 2. The Hague: Martinus Nijhoff Social Sciences Division.

Luhmann, N. (1984) Soziale Systeme. Grundriss einer allgemeinen Theorie. Frankfurt: Sulukamp

MacKenzie, D. (2004) 'Social Connectivities in Global Financial Markets', Environment and Planning D. Society and Space 22: 83-101.

Podolny, J. (2001) Networks as the Pipes and Prisms of the Market', American Journal of Sociology 107(1): 33-60.

Ritzer, G. (1994) Tlie MacDonaldization of America. Thousand Oaks, CA: Pine Forge Press.

Ritzer, G. (2002) The Globalization of Nothing. Thousand Oaks, CA: Pine Forge Press. 
Sageman. M. (2004) Understanding Terror Networks. Philadelphia, PN: University of Pennsylvania Press.

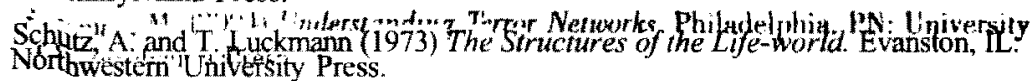

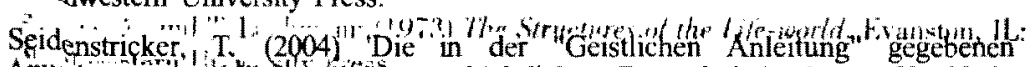
Anweisungen "und ihre teligionsgeschichtlichen Besonderheiten', pp. 29 in 38 in

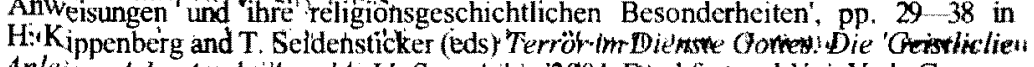

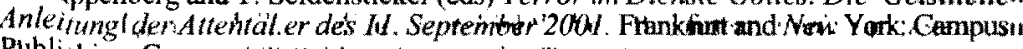

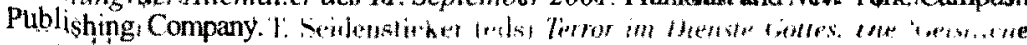

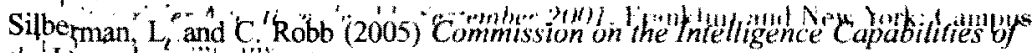

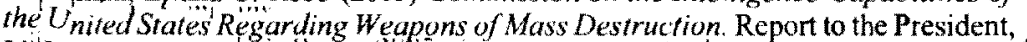

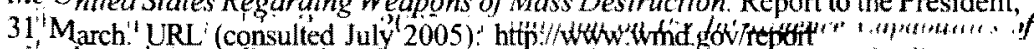

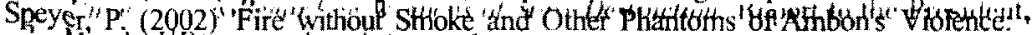

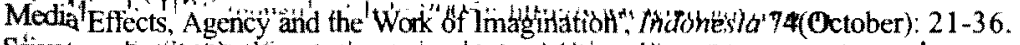

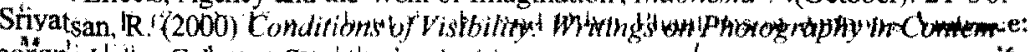

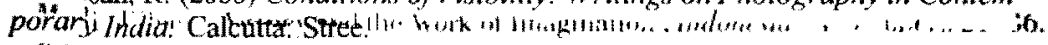

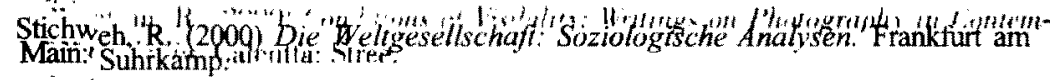

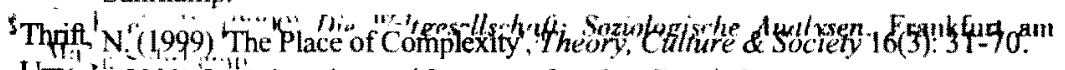
$\mathrm{U}_{\mathrm{mp}} \mathrm{J}^{\mathrm{V}}$ (2000) Soctiology beyond Societies. London: Routledge,

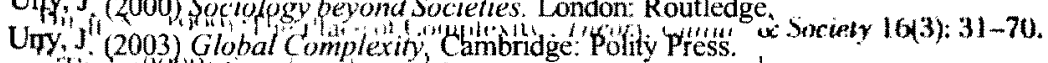
White, H. (1992) A A gency as Control in Fomal Networks, in $\mathrm{N}$. Nohria and R.G.

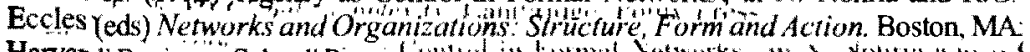

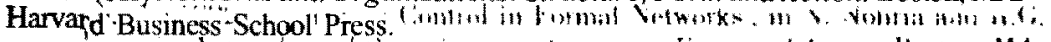

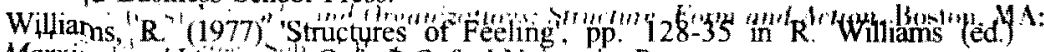
Marxis m and Literaturet Oxford? Oxford University Press

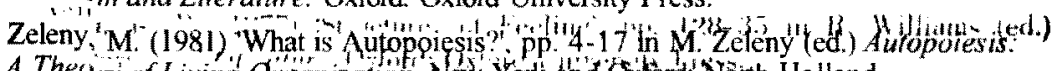

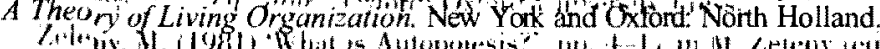

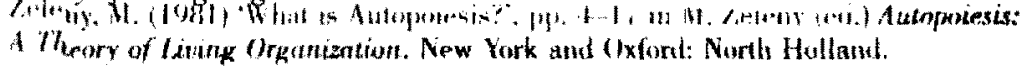

Karin Knorr Cetina is Professor of Sociology at the University of Constance, Germany, and Visiting Professor of Sociology and Anthropology

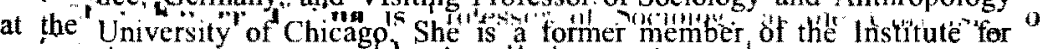

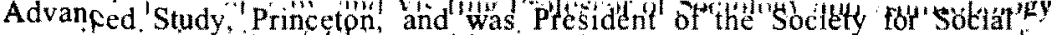

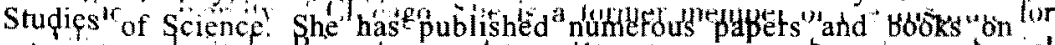

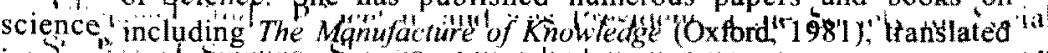

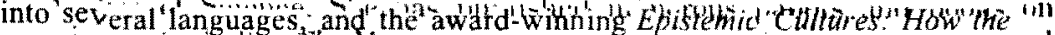

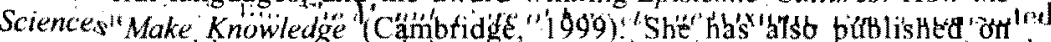

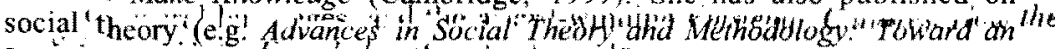

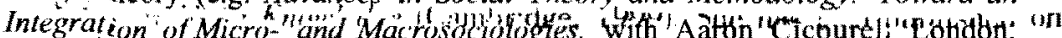

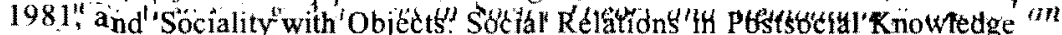

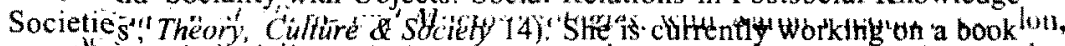

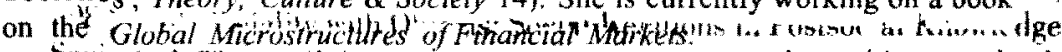

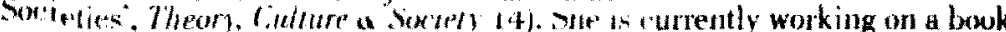
on the Global Microstructures of Financial Markets.
Theory, Culture Society Manuscript Central Website

Theory, Culture \& Societris now edited and refored electronically. This means that authors and reterees must submit manuscripts or obtain articles to referee vat tiie Ttiwiy, Culture \& Society Manuscript Cenlral website. This involves going to the site at:

htp: //mc manuscriptcentral com/tos

Preparation of Manuscripls

1. Authors should submit their manuscript, along with an abstract of 200 words.

2. Authors should also provide 3-7 keywords which must be selected firm the keyword lisl available on the TCS Manuscript Central website and need to be keyed in separately in the appropriate Hedl when (lie article is uploaded. The keywords are essential in helping editors select referees from our referees' database. If you have difficulty matching keywords, or have suggestions on ones to be added, please let us ksow.

3. To protect anonymity, please make sure that you do not include your name anywhere within the main document (e.g. as a running head or at the end).

4. The artick should begin with a separate cover page bearing only the title

5. The number and length of notes should be stricty limited. They should be numbered serially and included at die tnd of the text proor to the references section.

6. Please make sure you insert page numbers into your manuscript.

Format of References in the Text

Identify all relerences to books, monographs, articles and other sources at an appropriate point In the mam text by author's last name, year of publication, and pagination where appropriate, all within parentheses Specify subsequent citations of the same source similariy - do not use ibid,. op sit, or loe. tit.

If the oul hor's name is $m$ the lext, use only the year of publication in parentheses:

$$
\text { Lent (2001) }
$$

If the author's name is not in the text, include both the author's name and year of publication separated by comrna within the parentheses.

(Bauman, 1999]

Pagination folkns year:

What suthorship give

列

(Bennett et al., 1986; Hartik and Negri, 2000)

If there is more than one reference to Lit same author and year, distinguish between thern by use of tekters a b etc. attached to year of publication.

(Foucaul 1979a)

Frclose within a single pair of parentheses a series of references lister! alphabetically separated by semicolons: (Bourdieu, 1934; Dimaggio, 1987; Lamont, 1988)

\section{Formal of References}

List afi entries cited in the text, or any ather items used to prepare (he manuscript, atphabetically by euthor and year of publication in a separate references section at the end of the article. For typing format, set examples below:

Pieterse, J.N. (1997) Multicultnralism and Museums: Discourse and Others in (lie Age of Globalization', Theorv, Culture de Society 14,4):12,3-46.

Keamey, R. (ed) (1996) Pau Riciseur and the lerm encn. licis of Action. London: Sagge Publications. Harootunian, II. (200)1) Overcome hy Modernit3. Princeton, Nf. Princeton Univensity Press.

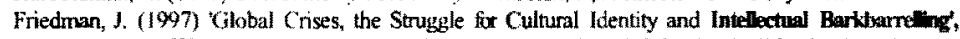
pp. 99-114 in P Wertuer and T Modood (eds) Debating Cuiturat (fybricily LoiddoniZcd Books.

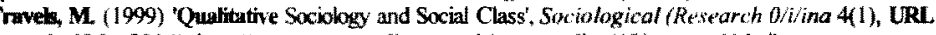
(consulted May 2004): http://www. socresonlinc. org.uk/socreaonline $4 / /$ travers. 11 in il

\section{Formal of Ouotations wiilim llie Texl}

For quotations within the text please make sure to use single inverted commas on all occasions, except for it

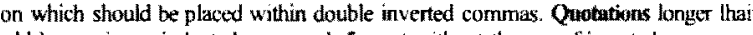
wo or three sentences should be put in an indented paragraph format without the usc of inverted commas

For more detailed information on manuscript submission please go to: hilp:/ttes.jitamiscriplcentral.com General queries about the journal can be dealt with more easily and rapidly by cmniling us nt tcs(angtn.ac.uk Mike Featherstance, Theorn, Cuiture \& Swciety Centre. School of Arts, Communication \& Culture, Notthngham TVert University, Clifion Lane, Nottingham NC11 8NS, Unthed Kingdom: Tel: ff 44 (0) 11584 6330; Fax: +44 (0)115848 6331: E-mail: (cs(a)ntu.ac.uk: WWW: http:/tes.ntu.ac.uk :

Aka, manuscript submissions via: http://mc.rnanuscripteentralcom/te 